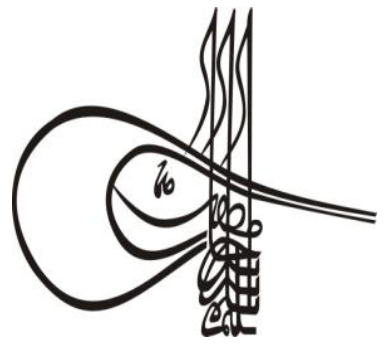

\section{Curkigh Studies CUDES 2019}

Volume 14 Issue 5, 2019, p. 67-80

DOI: 10.29228/TurkishStudies. 22991

ISSN: 1308-2140

Skopje/MACEDONIA-Ankara/TURKEY

Research Article / Araștırma Makalesi

Article Info/Makale Bilgisi

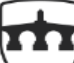

INTERNATIONAL BALKAN UNIVERSITY

EXCELLENCE FOR THE FUTURE IBU.EDU.MK

Go Report Dates/Rapor Tarihleri: Referee 1 (26.07.2019)-Referee 2 (26.07.2019)

This article was checked by iThenticate.

\title{
THE NEWS COVERAGE OF CHRISTCHURCH TERRORIST ATTACKS IN BRITISH MEDIA
}

\author{
Lale DÜNDAR*
}

\begin{abstract}
Vast majority of the violent attacks including the terrorist attacks are stored in the memory of the reader and the audience in the way it was covered by the mass media. Most of the studies show that societies perceive the attacks from the point of view of the media outlets. There is a direct relationship between the framing of the news and the perception of the society. The way a terrorist act is framed can influence the public opinion. Framing involves selecting particular aspects and angles of reality and privileging them in the description, the definition, the interpretation and the moral evaluation of the subject being covered. How to formulate and frame the news is important not only for influencing the perception of the public, but also to present objective news to the public. Objectivity is one of the main issues of the news media which is considered to be the hallmark of "good journalism". It is one of the most important criteria for testing the reliability of the news. Although it is claimed that objectivity is a myth, formulating and framing news is an important sign that shows the independence and intention of the journalist. Especially in the first moments of a terrorist act, citizens generally refer to the news media as the first source of information. During these moments, framing the news is much more crucial. Even a few words are enough to set up a frame that can influence the public. This study examines the news coverage of British media during the first moments of the terrorist attacks at two mosques in Christchurch, New Zealand and questions the editorial choices of British newspapers. A discourse analysis was conducted on news coverage of the Christchurch Mosques across the British daily newspapers. The language, representation, discourse and constructed meaning used in the news are the focus of the study.
\end{abstract}




\section{STRUCTURED ABSTRACT}

This study examines the news coverage of Christchurch terrorist attacks in British newspapers. The Christchurch mosque shootings by Brenton Tarrant were two consecutive terrorist attacks at mosques in Christchurch, New Zealand during Friday Prayer of Muslim community on 15 March 2019. The attacks began at the Al Noor Mosque in the suburb of Riccarton at 13:40 pm and continued at the Linwood Islamic Center around 13:55 pm. The Christchurch terrorist attacks was the first terrorist attack in history which was broadcasted live by the terrorist himself. The terrorist livestreamed the first attack live on Facebook and posted a "so called manifest" on social media. The attacks killed 50 Muslim worshippers and injured 50 others. (49 people died on the day of the terrorist attack and 1 more injured person died several days after the attack. Therefore, the news texts of $15^{\text {th }}$ and $16^{\text {th }}$ March mention only the loss of 49 people.) The Prime Minister of New Zealand, Jacinda Ardern stated that it was one of the darkest days of New Zealand.

This study focuses on the news coverage of the Christchurch attacks in British media and questions the editorial choices of British newspapers. The news coverage of British media during Christchurch attacks was criticized in terms of framing the news and providing a space for the propaganda of the terrorist. The terrorist livestreamed the attack from his Facebook account. This 17 minute long live stream was also announced previously from his other social media accounts. He had advertised the shooting previously. During and after the terrorist attack, materials like the video of the attack and the so called manifest were still readily available in British media. The Mail hosted the suspect's full manifest, which was also available for download directly from its website. The Sun, ran a clip from the video on its homepage. The Daily Mail and the Daily Mirror, published edited versions of the video to their websites. British Media was not only criticized because of broadcasting/printing the violent videos and the "so called" manifest of the terrorist act, but also for the way it frames the discourse. 10 of the British daily newspapers were examined for this study. In this paper, the news that are reported on the online version of the newspapers within 5 hours of the aftermath of the attack, and the ones that made the headlines in the printed editions the following day are examined. These newspapers are Daily Mail, Express, Guardian, Independent, Metro, Mirror, Telegraph, The Sun, Financial Times, and The Times.

This study mainly investigates three questions:

1- How is the perpetrator Brenton Tarrant named-represented in the news stories?

2- How is the occurrence named - represented in the news stories?

3- How are the victims represented and named in the news stories?

At least 6 frames were identified for the first question on the online platforms of the mentioned newspapers. The perpetrator has been named as: gunman, extremist, shooter, killer, angelic boy, white supremacist. The newspapers also framed the target of the attack, the people who were affected by this attack in several ways. They were represented as, worshippers, people, Friday worshippers, some 49 people, innocent worshippers, dozens and Muslim worshippers. When the findings are 
analysed it is found out that, although most of the online British newspapers name the incident as "a terrorist act" or "a massacre", not all of them are presenting the attacker as a "terrorist". Instead of using this terminology, they prefer to use terms like, white supremacist, extremist, gunman, suspect and killer to define the perpetrator. Among the investigated online British newspapers, only The Sun represents the attacker as a terrorist -among the headline news-. Mirror is the only one that attributes "innocent" adjective to the victims by using "innocent worshippers" term. It is noteworthy that there is no mention of the religion of the worshippers. Neither Islam nor Muslim words were used in the news texts while describing the victims on the online platforms. The same questions were investigated through the front pages of printed versions of the British Newspapers the day after the terrorist attack on $16^{\text {th }}$ of March 2019.

It was also found that, the front pages of the printed British newspapers mostly focused and criticized the social media platforms for publishing the manifest and the videos, instead of criticizing the attack itself. Some newspapers like Express even did not mention the perpetrator from the front page. Express also did not mention the loss of the victims who were affected from the attack, instead, Express claimed that the attack targeted the values. Daily Mail and Daily Telegraph also focused on the social media streams from their front pages instead of the murder of the 50 people. Interestingly, Independent is among the only newspaper that calls the perpetrator "Mr. Tarrant" which has a connotation of respect. The framing of the Daily Mirror was a special case, which was criticized widely. Daily Mirror preferred to name the perpetrator as: "Angelic boy" accompanying this headline with his childhood photo. This approach was criticized for underestimating and even legitimizing the terrorist act.

The news coverage of Christchurch terrorist attacks was a challenge for most of the local and international media outlets. Since the focus of this study is the British newspapers, it can be said that the British newspapers failed in terms of ethics and journalistic profession. The victims of the attack, -the Muslim minority community- were nearly not mentioned in the Christchurch coverage of British newspapers. While the so called manifest was shared from online newspaper platforms, which led to the propaganda of the terrorist, the attacker was not presented as a terrorist. Instead of presenting the terrorist and the terror act itself, most of the British newspapers choose to focus on the social media platforms and their role after the terrorist attacks.

This study once again reminds that the representation of events in the mass media could systematically affect how the audience interpret the facts. Therefore, especially in times of crisis such as terrorism and wars, newspapers and journalists have the responsibility to provide accurate information.

Keywords: Christchurch, New Zealand, terror, news, media 


\title{
İNGİLIZZ BASININDA CHRISTCHURCH TERRÖRİST SALDIRILARI
}

\begin{abstract}
ÖZET
Terör ve şiddet içeren saldırıların pek çoğu, okur ve izleyicinin hafızasında kitle iletişim araçlarının yayınlandığı şekliyle yer almaktadır. Pek çok çalışma, toplumların saldırıları medya kuruluşlarının bakış açısıyla algıladığını ortaya koymaktadır. Haberin çerçevelemesi ile toplum algısı arasında doğrudan bir ilişki bulunmaktadır. Bir terörist eylemin çerçevelenme şekli kamuoyunu etkileyebilir. Çerçeveleme, gerçekliğin belirli yönlerini ve açılarını seçmeyi ve bunları ele alınan konunun tanımı, tanımlanması, yorumlanması ve ahlaki değerlendirmesinde ayrıcalıklılaştırmayı içerir. Haberlerin nasıl formüle edileceği ve çerçeveleneceği, sadece toplumun algısını etkilemek açısından değil, aynı zamanda topluma nesnel haberler sunmak açısından da önemlidir. "İyi gazeteciliğin" nişanı olarak adlandırılan nesnellik, haber medyasının ana konularından biridir. Nesnellik, haberlerin güvenilirliğini test etmek için de en önemli kriterlerden biridir. Her ne kadar, haberlerde tarafsızlığın bir mit olduğu iddia edilse de, haberleri formüle etmek ve çerçevelemek gazetecinin bağımsızlığını ve niyetini ortaya koyan önemli bir işarettir. Özellikle bir terör eyleminin ilk anlarında, haber medyası genellikle vatandaşlar için ilk bilgi kaynağıdır. Bu anlarda, haberi çerçevelemek çok daha hayati önem arz etmektedir. Birkaç kelime bile kamuoyunu etkileyebilecek bir çerçeve oluşturmak için yeterlidir. Bu çalışma, Christchurch, Yeni Zelanda'daki iki camide terörist saldırıların ilk dakikalarında İngiliz gazetelerinin haberleri sunuş şeklini söylem analizi ile incelemekte ve İngiliz gazetelerinin editoryal seçimlerini sorgulamaktadır. Haberlerde kullanılan dil, temsil, söylem ve inşa edilen anlam çalışmanın odağını oluşturmaktadır.
\end{abstract}

Anahtar Kelimeler: Christchurch, Yeni Zelanda, terör, haber, medya.

\section{Introduction}

News is one of the most basic sources for public information. The right of individuals to receive information is assured in many international documents such as the Universal Declaration of Human Rights of the United Nations and the European Convention on Human Rights. The information cannot be hidden from public. Similarly, it is among the universal responsibilities of the journalists to present the news as close to the truth as possible without departing from the facts.

The news outlets and institutions that produce news, should provide objective and accurate information although journalists are expected to be objective, it has become a common belief that this is not a very realistic expectation in today's media. The language used in the news becomes one of the most important elements for ensuring the neutrality of the news. Because every chosen word, every photographic frame printed affects the objectivity of the presentation of the relevant event.

The messages provided by media plays a significant role in shaping geopolitical conditions and our understanding of the world. News frames, shape popular imaginations of topics of global concern such as wars, disasters, and crises. The need for objective and accurate information from the community is increasing in times of crisis such as terrorist attacks, natural disasters and wars. During such sudden 
developments, which are considered as breaking news or last-minute developments, the public meet the information need through the news media. Therefore, in times of crisis such as terrorism and wars, newspapers and journalists have the responsibility to provide accurate information. Crises occur abruptly, pose a threat or problem, create a danger, require urgent intervention, awaken large masses and determine the agenda. Crises also reveal emotional situations for individuals or the societies, that are difficult to cope with. Media is responsible for publicly notifying social, political, military economic or natural crises occurring in unexpected moments. Improper or incomplete information provided by the media during crises times, cannot be compensated. In times of crisis, mass media undertakes functions such as providing information flow, updating, expressing problems and guiding the masses. One of the issues that should be considered in crisis journalism is the manipulation through the news and its effect. Manipulation refers to information distortion and is considered to include steps to create behavioral or opinion changes in societies. People's sensitivities are at the highest-level during crisis situations. For this reason, even the smallest details in the news might have more impact on the lives of those concerned. (Çetinkuş, Keleş, 2018:119)

Many of the terrorist and violent attacks are remembered by the audience, in the way the mass media covered it. Most of the studies show that the societies perceive the attacks from the point of view of the media outlets. The studies show that, "The media play a central role in informing the public about what happens in the world, particularly in those areas in which audiences do not possess direct knowledge or experience" (Happer\&Philo, 2013:321)

There is a direct relationship between the framing of the news and the perception of the society. The way a terrorist act is framed can influence the public opinion. Framing involves selecting particular aspects and angles of reality and privileging them in the description, the definition, the interpretation and the moral evaluation of the subject being covered. How to formulate and frame the news is important not only for influencing the perception of the public, but also to present objective news to the public. It is one of the most important criterions to test the reliability of the news. Although most of the scholars argue that objectivity in news is a myth, formulating and framing the news is an important sign that shows the intention and the independence of the journalist. Especially during the first moments of a terrorist act, the news media is often the first source of information for citizens. During these moments, framing the news is much more crucial. Even a few words are enough to set up a frame that can influence the public.

Based on the influence of media on society, this study examines the news coverage of British media during the first moments of the terrorist attacks at two mosques in Christchurch, New Zealand. The Christchurch mosque shootings by Brenton Tarrant were two consecutive terrorist attacks at mosques in Christchurch, New Zealand during Friday Prayer of Muslim community on 15 March 2019. The attacks began at the Al Noor Mosque in the suburb of Riccarton at 13:40 pm, and continued at the Linwood Islamic Center around $13: 55 \mathrm{pm}$. This attack was the first time in history that the terrorist livestreamed the first attack live on Facebook. The terrorist also posted a "so called manifest" on social media. The attacks killed 50 people and injured 50 others. Jacinda Ardern, the Prime Minister of New Zealand, commented that it was one of the darkest days of New Zealand. This study analyses the news coverage of the Christchurch attacks in British media and questions the editorial choices of British newspapers. A discourse analysis was conducted on news coverage of the Christchurch Mosques across the British daily newspapers. The focus of the study is placed on the role of language, representation, discourse and meaning constructed by the media. Since this is a case study, the aim is to provide indepth understanding of smaller samples with regards to their specific contexts. The context in this study is British media in particular. However media is a wide field for a study like this. A limitation is therefore made to British newspapers. Also, this study is qualitative. Therefore, it does not aim to count or measure the occurrences of frames. Rather it aims to capture as broad a picture as possible, identifying unique frames, without giving credence to the frequency of certain frames. 
The study includes a literature review to better understand the relationship between news making process and the ideology. Therefore, the relationship between ideology and the concepts of news, framing, discourse analysis is underlined within the scope of news construction.

\section{Constructing News: Ideology Framing and Discourse}

One of the challenges in describing the news is that many people consider news as solely the occurrences around us. Many scholars underline the fact that this is not the real definition of the news, instead it is a reproduction process. While defining the concept of news, it must be first stated that, "News does not exist in reality outside of the individual and therefore does not qualify as an occurrence or event. Within the Western context, news is regarded as the reporting -representation- in the media of events, issues and trends. These may occur before, during or after actual incidents transpire." (Fourie,2008: 232)

While narrating the news, the occurrences are presented according to the built-in codes and the rules of the newspaper. The discourse is created with the gentle touches of the journalist's pen(Girgin, 2003:76). In other words news employees, who present the news as a text in a newspaper, choose the news and shape the narrative. This also gives a meaning to the news that is published. Each newspaper carries its own narrative style and professional rules within the framework of its own values (İşkar, 2014:3)

The idea that news can or should be neutral or objective came under heavy critism from news researchers. (Fourie, 2008 :240) As representation of events in the mass media could systematically affect how recipients come to understand these occurrences, the media are the primary source for the way we see the world. (O'Shaughnessy and Stadler, 2005:34) Framing is a way of classifying and categorizing information, allows audiences to make sense of and give meaning to the world around them (Goffman, 1974). It is in many ways tied very closely to Agenda Setting Theory. Both focuses on how media draws the public's attention to specific topics and set the agenda. But framing takes this a step further in the way the news is presented and creates a frame for that information. This is usually a conscious choice by journalists. In this case a frame refers to the way media as gatekeepers organize and present the ideas, events, and topics they cover. The theory was first put forth by Goffman, under the title of Frame Analysis, saying that people interpret what is going on around their world through their primary framework.

Girgin (2003: 49) argues that, mass media plays one of the most important roles in the process of political socialization. In particular, newspapers that have readers from all age categories and different layers have a distinct position among the means of mass communication the (Yatkın - N. Yatkın, 2006: 38). The news texts published in newspapers reach the masses and make intellectual contributions to society, therefore differs from other mass media in the way they influence the social values and masses (Girgin, 2003: 61-64). Considering the fact that newspaper news influences a qualified audience, it has serious effectiveness in guiding the social opinion leaders. From this point of view, the social role of newspapers is examined, and it is important to make sense that the ideological principles of the newspaper should be dealt with together. (Fiske, 2003: 214). What is meant here is that the newspaper has to re-establish its news on the ideological infrastructure it has, rather than making a presentation that reflects or distorts reality. The process of re-structuring or re-building reality on the basis of ideological views is not independent of the existing societal realities. Media, is not outside the memory of social consciousness (İskar, 2014: 2). And cannot isolate itself from social functions. On the contrary, the it provides a kind of function called mutual relation in the construction of social reality (Burton, 2008: 84). Van Dijk (1985: 6) underlines that:

"It is imperative that we come to know how final news items in the press or on TV are the ultimate results of a complex sequence of text processing stages. It has not sufficiently been realized that most news items are not directly based upon personal observations or experiences of journalists, 
but the result of a series of textual transformations of various forms of antecedent discourses, such as telex messages, reports, interviews, press conferences, documents, police records, eye witness testimony, and so on. In other words, most news production is a form of text processing. We should investigate which linguistic, cognitive and social factors impinge on this process." He also adds that, the communicative events such as the production and the consumption of media discourse have their goals and functions such as 'agenda setting' function. (Van Dijk, 1985: 7). Gieber (1964: 180) also focuses on the social context and states that: "News might be what news people make it, until we understand better the social forces which bear on the reporting of news, we will never understand what news is." It is obvious that there is a relation with the news reporting and the social context. News cannot be examined without the social context. According to Hall (1978:53) "The media do not simply and transparently report events which are neutrally newsworthy in themselves. News is the end product of a complex process which begins with a systematic sorting and selecting of events and topics according to a socially constructed set of categories".

The ability of the print media to determine public perception, to create social motivations, to change or consolidate established convictions and attitudes makes it an effective element in the formation of public opinion. As Girgin stated, (2003:120) "Public opinion is a social phenomenon shaped by various stages". The news has a function that legitimizes, reproduces and shapes the economic, political and ideological power within social dynamics. (Selçuk - Şeker, 2012:35-40). The narrative part of the news is inevitably influenced by institutional routines, production limits and journalistic values, and is therefore biased. (Akca, 2009: 87). One of the most important factors in the news texts, to create public opinion, is style. Style is the expression of the same event with different words and their conversion into text. The choices of ones style reveal his-her social and ideological influences, give information about preferences and the ideas of the journalist. Explicit comparison of media products across nations and cultures allows one to specify which thematic, stylistic, rhetorical, schematic, or other features of media discourse are imposed by dominant communication monopolies. In this way not only ideologies may be transmitted but also the very ways of production, writing, and reading/ viewing. (Van Dijk, 1985: 8)

In order to reveal the ideological codes in the news, the implicit meanings must be analyzed. Critical discourse analysis is generally used for this purpose. Discourse analysis looks the way the media positions the reality and classifies it. This categorization process also occurs for the language used. The tongue is also sided. It carries the value judgements and the weaknesses of the taboos in the society. There are also imaginative meanings outside the real meaning of words. Discourse analysis is not limited to the study of text structures. Meanings, ideas and ideologies are also revealed. Van Dijk (1985:5) takes media discourse primarily as "a basis for an inferential framework that is as expression, indicator, signal or as stimulus for other, underlying phenomena in culture and society, such as ideologies, power, dominance, discrimination, racism and sexism, media access of elites, or the users and effects of the media with the audience."

The selection of words also plays an important role in discourse analysis. The selected words are very important in terms of reflecting the world view of the messenger. The fact that the same person can be defined as a 'terrorist' or a 'freedom fighter' in the news shows the ideology of the reporter and the newspaper and the ideological atmosphere they belong. Word choices are directly related to the formation of meaning within the microstructures of news discourse and enable the reader to establish a general framework of events.

An important way to look at news is to identify the values that constitute the news. The news values are closely tied with the 5W's and the $\mathrm{H}$ of the news. Which are;

Who: The character in the event

What: The event itself 


\author{
Why: The cause \\ Where: The place \\ When: The time \\ How: The manner
}

Identifying these values, for instance defining "who" in a news story, mostly depends on the social, historical, political and economic forces. "Identity construction is not viewed as something that takes place only on a textualized an symbolic level removed from the everyday experiences of people. Rather we should see the construction of identity as taking place within the lived experience of people." (Fourie, 2008: 244)

\title{
News Coverage of Christchurch Mosques Attacks in British Media
}

The Christchurch terrorist attacks in New Zealand deserves to be investigated not only in terms of terrorism, politics or international relations, but also in the context of communication studies since, both traditional and the new media platforms, were heavily criticized.

This terrorist attack was the first time in history that was broadcasted live by the terrorist himself. The terrorist livestreamed the first attack live on Facebook and posted a "so called manifest" on social media. The attacks killed 50 Muslim worshippers and injured 50 others. The Prime Minister of New Zealand, Jacinda Ardern stated that it was one of the darkest days of New Zealand. Some British media outlets was reluctant to call the perpetrator as a terrorist. Although he openly identified himself as terrorist and his conduct as a terrorist act.

Christchurch attacks was the first time that a terrorist used live stream during this terrorist attack. Social media platforms like Facebook and Twitter were criticized for publishing the shooter's so-called manifest and video of the attacks. Social-media channels including Facebook, Twitter and Youtube removed the live broadcasted footage of the attack, from their platforms. Accounts associated with the suspected perpetrators were suspended, and copies of a 74-page manifest posted by one of the suspects were taken down not before than 10 hours.

"At the center of the shooter's media strategy was a sordid video: a 17-minute film broadcast live from a camera mounted to his military-style helmet. It showed the suspect in real time as he drove his car to his target, walked up to the mosque, and began shooting. His followers knew to tune in because he had advertised the shooting — and the fact that he would stream it live — on the message board site... Along with a link to his Facebook page, the shooter posted links to his 74-page manifesto spread across multiple sites." (Foreign Policy, 2019)

Not only social media but also the traditional media and newspapers were also criticized regarding their coverage of terrorism. During and after the terrorist attack, materials like the video of the attack and the so called manifest were still readily available in British media. The Daily Mail and the Daily Mirror, which are among the most popular newspapers in the United Kingdom, published edited versions of the video to their websites. The Sun, Britain's biggest-selling tabloid, also ran a clip from the video on its homepage. The Mail even hosted the suspect's full manifest, which was also available for download directly from its website. (Atlantic, 2019) Following the rise of criticisms, Lloyd Embley, the group editor-in-chief of Reach PLC, which publishes several British newspapers, including the Daily Mirror and Daily Express, tweeted and confirmed in a statement that the video was uploaded in violation of the newspaper's policies. Also, a spokesperson for the Mail said that publishing the manifest to its website was done "in error." (Atlantic, 2019), (NBC News, 2019) 

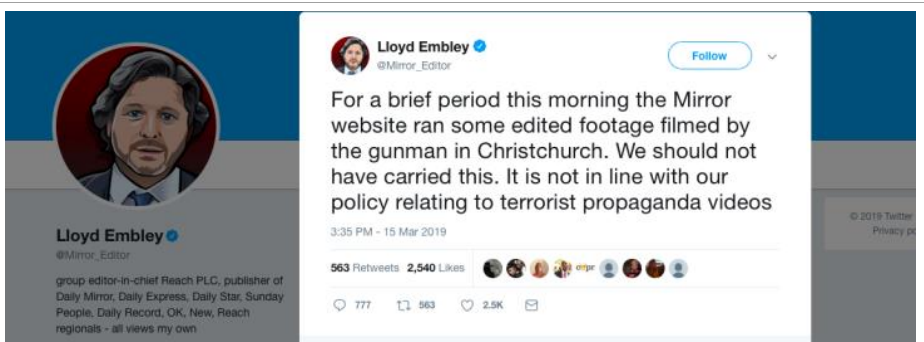

Figure 1. Tweet message of Lloyd Embley, the group editor-in-chief of Reach PLC, which publishes several British newspapers, including the Daily Mirror and Daily Express.

British Media was not only criticized because of broadcasting/printing the violent videos and the "so called" manifest of the terrorist act, but also for their news framing and discourse. In this study 10 of the British daily newspapers are examined Their online versions were examined during the first 5 hours of the attack, and the printed editions of the following day are examined. These newspapers include: Daily Mail, Express, Guardian, Independent, Metro, Mirror, Telegraph, The Sun and The Times and Financial Times.

As stated above, journalism is pretty much defined by five questions. And in framing process, it is important to answer each of these questions accurately. 1)Who is the shooter? 2) A terrorist, an extremist, a gunman or a shooter? 3) How should he be identified? 4)Why did this happen? 5)What was the motivation of the shooter? 6)How to name the attack? The answers of these questions appear in the news texts, give us an idea about the position of the British media. This study mainly investigates the following three questions:

1- How is the perpetrator Brenton Tarrant named/represented in the news stories?

2- How is the occurrence named /represented in the news stories?

3- How are the victims represented/named in the news stories?

In the analysis of the collected material, this paper identifies at least 6 frames for the first question on the online platforms of the mentioned newspapers. (see Figure 2 below). The headlines of the news on online platforms that are investigated reveal that he has been named as: gunman, extremist, shooter, killer, angelic boy, white supremacist. The way the target of the attack was framed by the newspapers are the following: worshippers, people, Friday worshippers, some 49 people, innocent worshippers, dozens and Muslim worshippers.

\begin{tabular}{|l|l|l|l|l|l|l|l|l|}
\hline & EXPRESS & GUARDIAN & $\begin{array}{l}\text { INDEPEN } \\
\text { DENT }\end{array}$ & METRO & MIRROR & TELEGRAPH & THE SUN & $\begin{array}{l}\text { THE } \\
\text { TIMES }\end{array}$ \\
\hline $\begin{array}{l}\text { Who } \\
\text {-the } \\
\text { perpetrator- }\end{array}$ & $\begin{array}{l}\text { White } \\
\text { Supremacist / } \\
\text { Gunman }\end{array}$ & $\begin{array}{l}\text { Rightwing } \\
\text { Extremist/ } \\
\text { Gunman/ } \\
\text { The man }\end{array}$ & $\begin{array}{l}\text { Shooter/ } \\
\text { Australian } \\
\text { suspect }\end{array}$ & $\begin{array}{l}\text { White } \\
\text { Suprem } \\
\text { acist }\end{array}$ & $\begin{array}{l}\text { Gunmen / } \\
\text { Killer }\end{array}$ & $\begin{array}{l}\text { Suspect/ } \\
\text { Gunman }\end{array}$ & $\begin{array}{l}\text { White } \\
\text { Supremacist/ } \\
\text { Gunmen/ } \\
\text { Shooter/ } \\
\text { Terrorist }\end{array}$ \\
\hline What & $\begin{array}{l}\text { Terror/ Mosque } \\
\text { Massacre }\end{array}$ & $\begin{array}{l}\text { Terrorist } \\
\text { Attack/ } \\
\text { Christchurch } \\
\text { Shooting/ } \\
\text { Mass } \\
\text { Shootings }\end{array}$ & $\begin{array}{l}\text { Terror } \\
\text { Attack/ } \\
\text { Mass } \\
\text { Shooting }\end{array}$ & $\begin{array}{l}\text { Terror } \\
\text { attack }\end{array}$ & $\begin{array}{l}\text { Terror } \\
\text { attack }\end{array}$ & $\begin{array}{l}\text { New Zealand } \\
\text { shootings/ } \\
\text { Christchurch } \\
\text { terror attacks }\end{array}$ & $\begin{array}{l}\text { Mosque } \\
\text { Shootings/ } \\
\text { Livestream } \\
\text { terror }\end{array}$ & $\begin{array}{l}\text { Terrorist } \\
\text { attacks }\end{array}$ \\
\hline $\begin{array}{l}\text { Who } \\
\text {-the victims- } \\
\text { affected } \\
\text { from the } \\
\text { attack }\end{array}$ & Worshippers & $\begin{array}{l}\text { At least } \\
\text { people }\end{array}$ & $\begin{array}{l}\text { Friday } \\
\text { Worshipp } \\
\text { ers }\end{array}$ & $\begin{array}{l}\text { Some 49 } \\
\text { people }\end{array}$ & $\begin{array}{l}\text { Innocent } \\
\text { worshippers }\end{array}$ & Worshippers \\
people/ & $\begin{array}{l}\text { Muslim } \\
\text { Worshippers }\end{array}$ & $\begin{array}{l}\text { Dozens } \\
\text { killed/ } \\
\text { Worshipper } \\
\text { s }\end{array}$ \\
\end{tabular}

Figure 2: Framing of Online Platforms of the British Newspapers right after the terrorist attack 
An analysis of the findings reveal that most of the online British newspapers name the incident as "a terrorist act" or "a massacre", however a limited number of them present the attacker as a "terrorist". Instead of calling the perpetrator as a terrorist, they choose to use terms like, white supremacist, extremist, gunman, suspect and killer to define the perpetrator. Among the investigated online British newspapers, only The Sun represents the attacker as a terrorist (among the headline news). It is also observed that the representation of the victims varies in those investigated newspapers. Most of the newspapers represented the victims in numbers such as: 49 killed, 49 people, dozens killed. Some of them named the victims as worshippers or Friday worshippers. Mirror is the only newspaper that uses the adjective "innocent" for the victims. However the religion of the worshippers are not mentioned anywhere. On the online platforms, neither Islam nor Muslim is mentioned as an adjective in the news texts while describing the victims.

The front pages of the printed versions of the British newspapers are investigated in the same manner one day after the terrorist attack on $16^{\text {th }}$ of March 2019. (See Figure 3 below)

\begin{tabular}{|c|c|c|c|c|c|c|c|c|}
\hline & EXPRESS & $\begin{array}{l}\text { INDEPEN } \\
\text { DENT }\end{array}$ & $\begin{array}{l}\text { DAILY } \\
\text { MIRROR }\end{array}$ & THE SUN & $\begin{array}{l}\text { FINANCIAL } \\
\text { TIMES }\end{array}$ & $\begin{array}{l}\text { DAILY } \\
\text { MAIL }\end{array}$ & $\begin{array}{l}\text { DAILY } \\
\text { TELEGRAPH }\end{array}$ & GUARDIAN \\
\hline $\begin{array}{l}\text { Who } \\
\text {-the } \\
\text { perpetrator- }\end{array}$ & $\begin{array}{l}\text { Not } \\
\text { mentioned }\end{array}$ & $\begin{array}{l}\text { Mosque } \\
\text { Gunman/ } \\
\text { Mr. Tarrant }\end{array}$ & $\begin{array}{l}\text { Angelic Boy/ } \\
\text { Little Boy/ } \\
\text { Mass Killer/ } \\
\text { Gunmen / } \\
\text { Killer } \\
\end{array}$ & $\begin{array}{l}\text { Maniac/ } \\
\text { Racist/ }\end{array}$ & $\begin{array}{l}\text { Right wing } \\
\text { gunman/ } \\
\text { Suspect }\end{array}$ & $\begin{array}{l}\text { Mosque } \\
\text { Killer }\end{array}$ & $\begin{array}{l}\text { Far-right racist/ } \\
\text { Tarrant,28 from } \\
\text { Australia }\end{array}$ & Gunman \\
\hline What & Massacre & $\begin{array}{l}\text { Muder of } \\
49 \text { people/ } \\
\text { Massacre }\end{array}$ & Massacre & $\begin{array}{l}\text { Mosque } \\
\text { Massacre }\end{array}$ & $\begin{array}{l}\text { Deadly New } \\
\text { Zealand } \\
\text { Mosque } \\
\text { Attacks/ } \\
\text { Far right } \\
\text { violence }\end{array}$ & $\begin{array}{l}\text { Massacre } \\
\text { Shame of } \\
\text { Facebook / } \\
\text { Terror } \\
\text { Attacks }\end{array}$ & $\begin{array}{l}\text { Social Media } \\
\text { Terror Attack }\end{array}$ & $\begin{array}{l}\text { Mass } \\
\text { Shootings/ } \\
\text { Terrorist } \\
\text { Attack }\end{array}$ \\
\hline $\begin{array}{l}\text { Who } \\
\text {-the victims- } \\
\text { affected } \\
\text { from the } \\
\text { attack }\end{array}$ & $\begin{array}{l}\text { Attack on } \\
\text { values that } \\
\text { unite us all }\end{array}$ & $\begin{array}{l}\text { Friday } \\
\text { Worshippe } \\
\text { rs }\end{array}$ & 49 murdered & $\begin{array}{l}\text { Worshipp } \\
\text { ers }\end{array}$ & Not mentioned & $\begin{array}{l}\text { Not } \\
\text { mentioned }\end{array}$ & 49 & $\begin{array}{l}49 / \\
\text { Friday Prayers }\end{array}$ \\
\hline
\end{tabular}

Figure 3: Framing of Front Pages of Printed Versions of the British Newspapers the day after the terrorist attack

When the front pages of the printed British newspapers are analyzed it is found out that, the newspapers mostly focused and criticized the social media platforms for publishing the manifesto and the videos, instead of criticizing the attack itself. Some newspapers like Express even did not mention the perpetrator from the front page. Express also did not mention about the victims who were affected from the attack, instead of mentioning the loss of 49 lives, Express claimed that the attack targeted the values. Daily Mail and Daily Telegraph also focused on the social media streams from their front pages instead of the murder of the 49 people. Interestingly, Independent is among the only newspaper that calls the perpetrator "Mr. Tarrant" which has a connotation of respect. This kind of news writing approach, showing this much respect to a terrorist obviously deserves further academic investigation.

The Guardian was also criticized for initially failing to describe the attack as a terrorist incident, instead referring to it in headlines as a "mass shooting". Later stories used "terror attack" in headlines. (Press Gazette. 2019) 
The framing of the Daily Mirror was a special case. Because the Daily Mirror preferred to name the perpetrator as: "Angelic boy" accompanying this headline with his childhood photo. Naming him an "Angelic boy" with his childhood photo, was criticized for underestimating and even legitimizing the terrorist act. (See Figure 4)
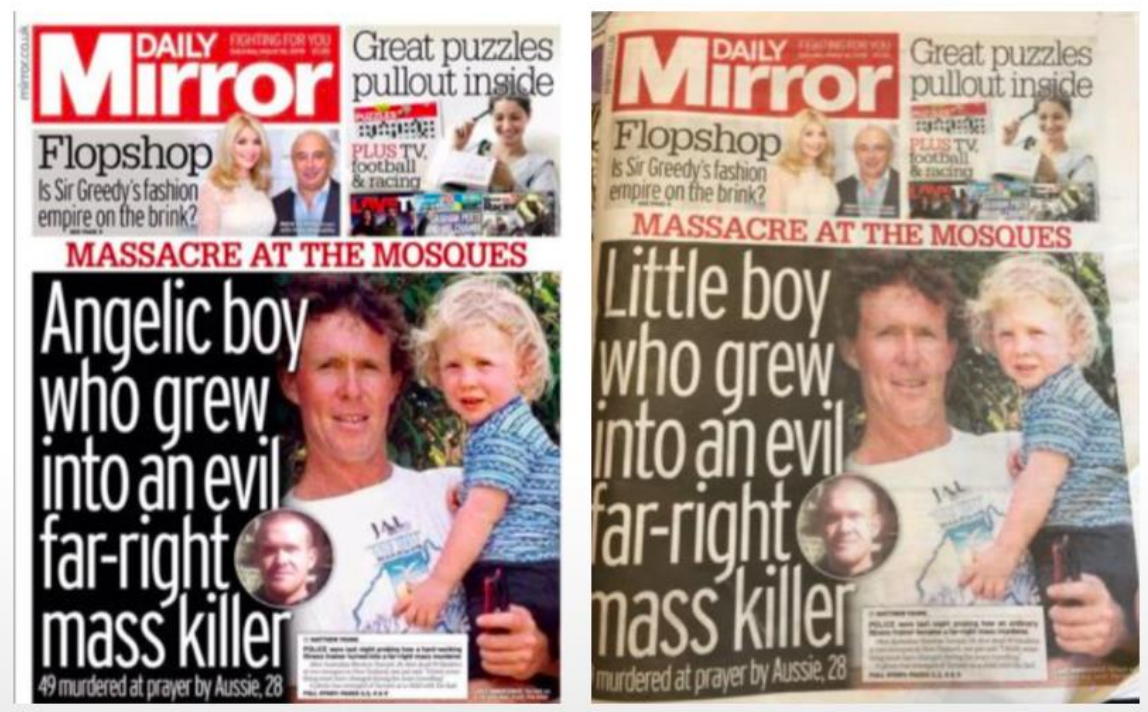

Figure 4: Daily Mirror's front pages on $16^{\text {th }}$ March 2019 - Left: first edition, Right: second edition

With the rise of criticism towards the Daily Mirror's framing, the Daily Mirror changed its front page headline on Saturday after first describing the suspect in the New Zealand mosque massacre, who broadcast the attack on Facebook Live, as "angelic". The headline on an earlier edition of the paper ran: "Angelic boy who grew into an evil far-right mass killer". It was later changed to read "Little boy..." (Press Gazette. 2019) The approach of the Daily Mirror is criticized because of focusing the perpetrator instead of the victims and the terrorist act. Framing the terrorist attack to an angelic boy does not meet the universal criteria's of "good journalism" that was stated above. Ignoring the terrorist act, the motivation behind it and the victims and focusing on the "innocence childhood" of the terrorist can not be categorized as ethical.

When the international documents are examined, it will be clear that the Christchurch attacks should be considered as terrorist attacks. According to the UNESCO's publication: UNESCO: Terrorism and the Media- A Handbook for Journalists (UNESCO: 53) there are three criterias for characterisation of terrorism in news texts. They are: "The deliberate targeting of civilians; the goal, beyond the victims, of affecting public opinion as broadly as possible and the intention to create a psychological impact that is greater than the physical damage caused." Since the Christchurch attacks fully meet these criterias, there should be no questions to name the attack as a terrorist attack or not. Avoiding to use the terms; terrorist or terrorist attack can be considered as violating the ethic rules of journalism.

Columbia Journalism Review (CJR) states that the British media violated the ethic guidelines while covering the Christchurch attacks. CJR states that: "UK papers' willingness to amplify the shooter's ideas was not limited to tabloids. The Guardian's US edition also violated all seven guidelines, and five Guardian stories were shared more than 50,000 times each. The BBC violated six of seven guidelines, and their most popular story-which included the shooter's name and the name of his manifesto-was shared almost 700,000 times on Facebook." (Columbia Journalism Review, 2019.) 


\section{Conclusion}

The news coverage of Christchurch terrorist attacks was a challenge for most of the local and international media outlets. Since the focus of this study is the British newspapers, it can be said that the British newspapers failed in terms of ethics and journalistic profession. The coverage in the British newspapers about the victims of the Christchurch terrorist attacks, the Muslim minority community, was limited if not absent entirely. The so called manifest of the perpetrator, who was not called a terrorist at all, was shared by the online newspaper platforms and this action contributed to his the propaganda. The British newspapers instead of presenting the terrorist and the terror act itself, have chosen to focus on the social media platforms and the role that have been played by them in the aftermath the terrorist attack. The scholars argue that this is the general tendency of the media outlets. According to Hall, minority groups are usually associated with crime (Hall, 1978), whereas crimes against them, such as racist or violent attacks, is under-represented. (Dijk, 1988: 13)

In this case while constructing the news, the questions of 'where' and 'when' are also undoubtedly very important. The target of attacks are the mosques and the attacks occur during the Friday prayer a sacred moment for the Muslims. Examining the news stories, it was realized that all these important elements were made nearly invisible in the news. This approach cannot be considered as a simple editorial choice. As mentioned above, ideology comes into being with words. And this selection cannot be analyzed without the influence of social, cultural, historical and political contexts. As Thomson (1990: 56) emphasizes meanings serve power. Therefore it is necessary to ask questions why certain words or images are used in particular contexts. By the repetition of particular kinds of images and stories, values and ideologies are transferred to the public via the news stories. As Fowler comments: "Nearly all meanings are socially constructed. All discourse is a social product and a social practice. News is analysed as a particularly important example of the power of all language in the social construction of reality"

To conclude it must be said that, the media have the power to use any word by their own will, due to their freedom of expression and the definition of their editorial line. But the universal responsibilities of the journalist should be reminded especially during the crisis times. "Media covering the incident had to make sure they did their jobs as journalists and told the story of what was happening, but did not amplify the message of hate or assist the circulation of propaganda. In Britain, some media woefully failed this test of their professionalism." (Ethical Journalism: 2019) When covering acts of terrorism and mass violence it is vital that news medias should show restraint. The journalists need to think carefully before the publication of disturbing content, particularly showing explicit images of violence or human suffering. Also how to frame and how to name the event, the people, the venue are crucial in news writing process. It is already known that, views, values are not ideologically neutral. But it must be reminded that news can lead to a divisive view of the society based on a distinction between "us and "them".

\section{REFERENCES}

Akca, B., Emel. (2009). İdeoloji-Dil-Söylem ve Anlam İlişkisi: Medyada Anlamın Toplumsal İnşaası: Medyada Gerçekliğin İnşası. ed. İsmet Parlak. Konya: Çizgi Kitapevi.

Burton, Graeme. (2008). Görünenden Fazlası. İstanbul: Alan Yayıncılık.

Çetinkuş, Hayri, Keleş, Necati. (2018). Muhabir: Habercinin Temel Kitabı. Ankara: Anadolu Ajansı Yayınları.

Dijk, Teun A. Van (1985). Discourse and Communication: New Approaches to the analysis of mass media discourse and communication / ed. By Teun A. Van Dijk.- Berlin; New York; de Gruyter. 
Dijk, Teun A. Van. (1988). News As Discourse. New York: Routledge.

Fiske, John. (2003). İletişim Çalışmalarına Giriş. Ankara: Bilim ve Sanat Yayınları.

Fourie, Pieter J. (2008). Media Studies: Policy, Management and Media Representation. Cape Town, South Africa: Juta Press.

Fowle, Rogers (1991). Language in the News: Discourse and Ideology in the Press. London: Routledge , Taylor and FrancisGroup.

Gieber, W. (1964). News is what newspaperman makes it. In L. A. Dexter \& D. M. White (Eds.), People, society, and mass communication. Newark, NJ: Free Press.

Girgin, Atilla. (2003). Yazılı Basında Haber Ve Habercilik Etiği. 2. Ed. İstanbul: İnkılap Yayıncılık.

Goffman, Erving. (1974). Frame analysis: An essay on the organization of experience. Cambridge, MA: Harvard University Press.

Hall, S., Critcher, C., Jefferson, T., Clarke, J., \& Roberts, B. (1978). Policing the crisis. Mugging, the state and law and order. London: Methuen.

Happer,C., Philo, G.(2013) The Role of the Media in the Construction of Public Belief and Social Construction. Journal of Social and Political Pscyhology, Vol. 1(1), 321-335 . Ed.Andrew Livingstone, Special Thematic Section on Societal Change. 2195-3325

İşkar, Erhan. (2014). İspanya İle ETA Arasında Yürütülen Terör Müzakerelerinin Yazılı Basında Ele Alınış Biçiminin Söylem Analizi. Yüksek Lisans Tezi. Ankara: T.C. Kara Harp Okulu Savunma Bilimleri Enstitüsü Güvenlik Bilimleri Ana Bilim Dalı.

O'Shaughnessy, Michael, Stadler, Jane. (2005). Media and Society.Oxford University Press.

Selçuk, Ayhan, Mustafa Şeker. (2012). Danıştay Saldırısı Haberlerinde Söylem ve İdeoloji.1. bs. Ankara:Nobel Yayınları.

Thompson, J.B. (1990) Ideology and Modern Culture. Cambridge: Polity Press.

Yatkın, Ahmet, Ümmühan, N.,Yatkın. (2006). Halkla İlişkiler ve İletişim. 2. Ed. Ankara: Nobel Yayın Dağıtım.

\section{WEB}

Atlantic (2019) https://www.theatlantic.com/international/archive/2019/03/british-mediachristchurch-mosque-new-zealand/585076/ Date of Access: 04.05.2019

Columbia Journalism Review: What we learned from analyzing thousands of stories on the Christchurch shooting: https://www.cjr.org/analysis/christchurch-shooting-mediacoverage.php Date of Access: 04.05.2019

Ethical Journalism (2019) https://ethicaljournalismnetwork.org/resources/publications/ethicaljournalism/case-study Date of Access: 04.05.2019

Foreign Policy (2019). https://foreignpolicy.com/2019/03/15/how-the-christchurch-shooterplayed-the-worlds-media/ Date of Access: 04.05.2019

NiemanLab (2019) https://www.niemanlab.org/2019/04/in-europe-media-narratives-aboutmigration-are-deeply-shaped-by-national-press-culture/ Date of Access: 04.05.2019

NBC (2019) https://www.nbcnews.com/news/world/news-outlets-mostly-avoided-publishingvideo-new-zealand-attacks-n983806 Date of Access: 03.05.2019 
Press Gazette UK (2019). https://pressgazette.co.uk/daily-mirror-changes-splash-headlinedescribing-mosque-killer-as-angelic-boy/ Date of Access: 04.05.2019

UNESCO: Terrorism and the Media- A Handbook for Journalists https://unesdoc.unesco.org/ark:/48223/pf0000247074 Date of Access: 04.05.2019 